\title{
Some Histo-physiological Effects of Azadirachta excelsa (Jack) Leaf Extract on Reproductive Organs and Fertility of Female albino Mice (Mus musculus)
}

\author{
Waad S. Shaher \\ Department of Biology \\ College of Science \\ University of Mosul
}

(Received 30 / 4 / 2013 ; Accepted 10 / 6 / 2013)

\begin{abstract}
This study was conducted to investigate the effect of ethanol leaf extract of Azadirachta excelsa oral dose (250 $\mathrm{mg} / \mathrm{kg}$ of b.w.) every other day for 28 days on the histological changes of the ovary and uterus, serum levels of progesterone and estrogen and the fertility of adult female mice.

The results showed histological changes in the ovaries of the treated groups indicating an increase in the number of secondary follicles, absence of the mature follicles, presence of the atretic follicles, bleeding tissue and congestion of blood vessels in the second group, while in the third group, they showed a decrease in the number of the primary and secondary follicles, absence of the mature follicles, presence of the atretic follicles and fibrosis of the ovarian cortex.

The uterus sections of the treated groups showed fibrosis of the uterus wall, hyperplasia of smooth muscle in the second group and papilloma of endometrium, congestion of blood vessels of serosa in the third group. The results observed a significant increase in progesterone and estrogen levels of the treated groups compared with control. The results observed an obvious decrease in the mean of newborn of the treated groups, which proved reduction of the fertility of the treated females. Thus, the application of this plant extract is important in the rodent control programs.
\end{abstract}

Keywords: Azadirachta excelsa, leaf extracts, ovary, uterus, fertility, mice.

\section{بzadirachta excelsa (Jack) بهض التأثيرات النسجية والفسلجية لمستخلص أورق

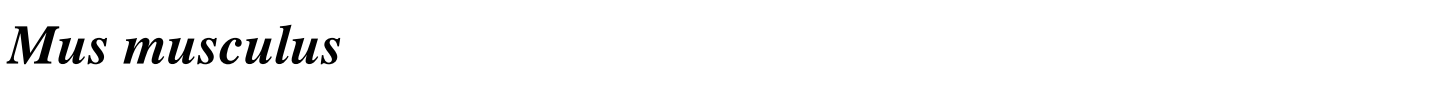

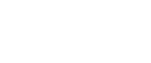

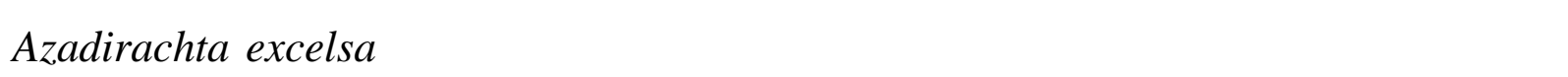

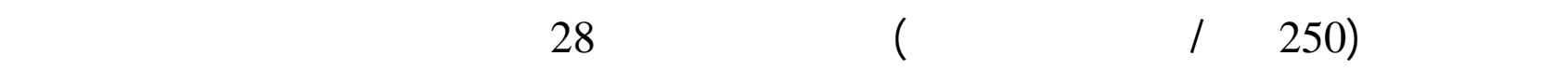

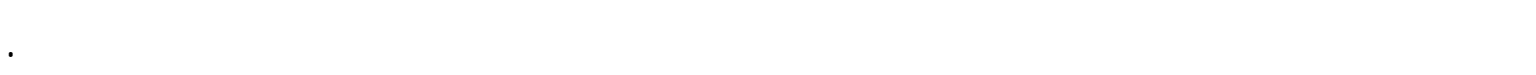

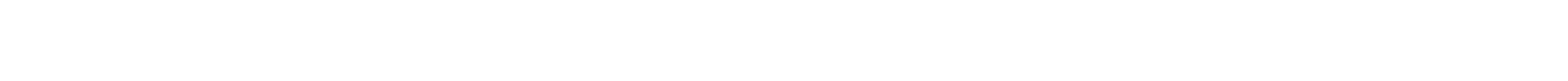
وغيلب الجريبت الناضجة ووجود الجريبت الرتقية ونزف نسجي ولحقلن الاوعية الموية في المجموء 
الثانية. بينما لظعهرت المجموعة الثالثة انخفاض عدد الجريبت الاولية والثانوية، غيلب الجريبت الناض جة،

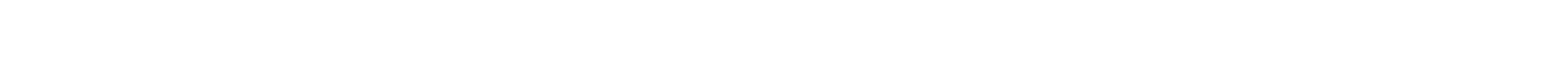

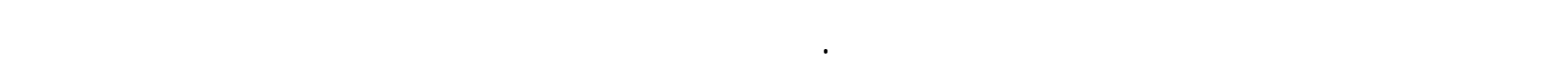
الطقة المصلية في المجموعة الثالثة.

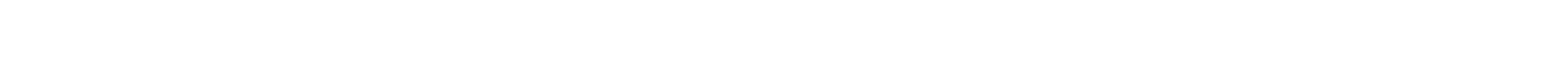

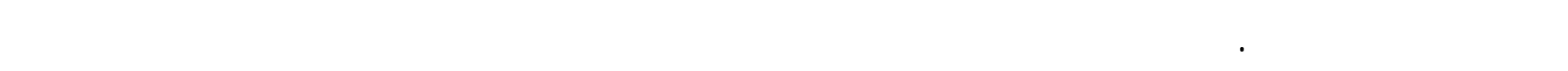

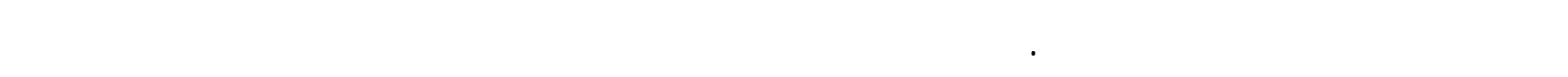

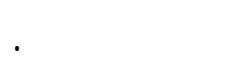

\section{INTRODUCTION}

Meliaceae family is commonly known as an important medicinal plant which includes Azadirachta excelsa, Azadirachta indica and Melia azedarach. A. excelsa tree whose various parts have been used as traditional medicine, insecticidal, antifertility (Sadre et al., 1983; Chungpongse and Buranatham, 1991; Lean et al., 2003; Akhtar et al., 2008; Shaher, 2009). A. excelsa leaf extract has highest yield of azadirachtin (Nor Aini and Seong, 2006).

Antifertility effects of $A$. indica leaf extract have been reported by (Upadhyay et al., 1990) they reported that female Wister rats of proven fertility were given a single dose $(100 \mu \mathrm{l})$ of neem (A. indica) Oil by intrauterine route, the treated females remained infertile for variable periods ranging from 107-180 day even after repeated matings with males of proven fertility whereas all control animals became pregnant and delivered normal litters.

A. indica seed extract inhibition of folliculogenesis (Roop et al., 2005), this extract caused immune-contraceptive activity (Murkherjee et al., 1999; Garg et al., 1998). Other plants have anti-abortive effect (Ma et al., 2012).

The crude leaf extract of $A$. indica caused an increase of progesterone levels in female rats (Akpanth et al., 2010), in another study the extract reduced the serum levels of testosterone and lutinzing hormones (Parshad et al., 1994; Ragi et al., 2003). The leaf extracts of A. excelsa up to $200 \mathrm{ppm}$. were much more effective than Melia azedarach, the extract of A. indica was in the third place. (Doll and Schumutterer, 1993; Schumutterer and Doll, 1993; Hein, 1994). The objective of this study was to determine the effect of $A$. excelsa fresh leaves extract on reproductive organs, serum levels of progesterone and estrogen and the fertility of female mice.

\section{MATERIALS AND METHODS}

Plants: Fresh green leaves of Azadirachta excelsa were collected from the garden of University of Mosul in April 2011. The leaves were washed in running tap water and crushed to be perpetrated for the extract.

\section{Preparation of the extract:}

The method of plant extraction was modified from (Sadre et al., 1983; Shaher, 2009). 100 grams of fresh leaves of $A$. excelsa was crushed by electric grinder, the mixture was macerated with $250 \mathrm{ml}$ of $75 \%$ ethanol solution and left to stand at room temperature for 48 
hours, for thorough extraction of the plants' active components, these were then filterd with cheese cloth and later with whatman no.1filter paper by suction and the filtrate was evaporated under vaccum at $40 \mathrm{C}^{\circ}$ until completely dried yielding brown oily $A$. excelsa. The extract was then refrigerated at $4 \mathrm{C}^{\circ}$ until use. Distilled water was used to dilute this stock solution to concentration of $250 \mathrm{mg} / \mathrm{kg}$.

\section{Animals}

In this study (33 female and 9 male) 3 months old, weighting (22-26g) were used. The females were divided into 3 groups of 11 female isolated in plastic cages. The first group was given $0.2 \mathrm{ml} \mathrm{d.w}$. and regarded as a control group. The second group was forced feeding orally dose of $A$. excelsa leaf extract $(250 \mathrm{mg} / \mathrm{kg})$ of body weight every other day for 2 weeks. The third group was given extract $(250 \mathrm{mg} / \mathrm{kg}$ ) of b.w. also every other day for 4 weeks. All groups were exposed to constant laboratory condition, temperature was about $\left(25 c^{\circ} \pm 2\right)$ and light/dark cycle of $12: 12 \mathrm{~h}$. and fed with standard commercial diet and given water.

Five females of the second treated group were ansthetized after 2 weeks with chloroform. Blood was collected from orbital sinus puncture, the sample was put in the refrigerator for 15 minutes, then centerfugation with (REMI Motors LTD) centrifuge to isolate the serum, progesterone and estrogen levels determined by a diagnostic kit (ELISA) method. These females dissected, ovary and uterus isolated and put in neutral formalin for hisological study. After routine preparations, the organs were embedded in paraffin and sections were cut with $5 \mu$ and staind with double stain hematoxylin-eosin (Luna, 1968. ALHajj, 2010). The other six females of the second treated group were mated with untreated males (one male with two females) to proven fertility. After one week the males were removed from the cages. The pregnant females were observed daily during 3 weeks of gestation, the number of offspring from each female was recorded as soon as possible after birth. The same step was applied with the third treated group and the control group after 4 weeks.

The microscopic photos of tissue sections were taken using OLYMPUS optical microscope, Japan origin, with digital camera type MDLE5. The measurement of magnification $(\mathrm{X})$ by using the way was as follows:

Magnification power $(\mathrm{X})=\frac{\text { Value measurment of the stage micromiter picture with } \mathrm{Cm}}{\text { Number of divistoin } \text { taken } \times 10}$

\section{RESULTS}

The effects of oral administration of fresh leaf extracts of Azadirachta excelsa ( $250 \mathrm{mg} / \mathrm{kg}$ of b.w.) every other day for 28 days showed histological changes in the ovary and uterus of the treated groups compared with the control one.

Ovary: histological sections of the control group showed normal Ovarian morphology, covering epithelium (tunica albuginea), cortex (stroma) and medulla. The stroma was made up of reticular fibers and fusiform cell with follicular cells at different stages of development. (Fig. 1).

The second treated group with $250 \mathrm{mg} / \mathrm{kg}$ of b.w. of $A$. excelsa leaf extract for 2 weeks showed an increased in the number of the secondary follicles, absence of the mature follicles, presence of the atretic follicles, bleeding tissue and congestion of the blood vessels in medulla of the ovary. (Fig. 2). The third treated group for 4 weeks showed a decrease in 
the primary and secondary follicles, absence of the mature and presence of the atretic follicles and fibrosis of the ovarian cortex. (Fig. 3, a, b). Uterus: the control revealed a normal uterine, histological sections showed the endometrium made up of a single layer of columnar epithelium deep to it, but it was the lamina propria which connected it with compactly arranged smooth muscle layer, the myometrium. The myometrium was surrounded by the serosa. (Fig. 4).
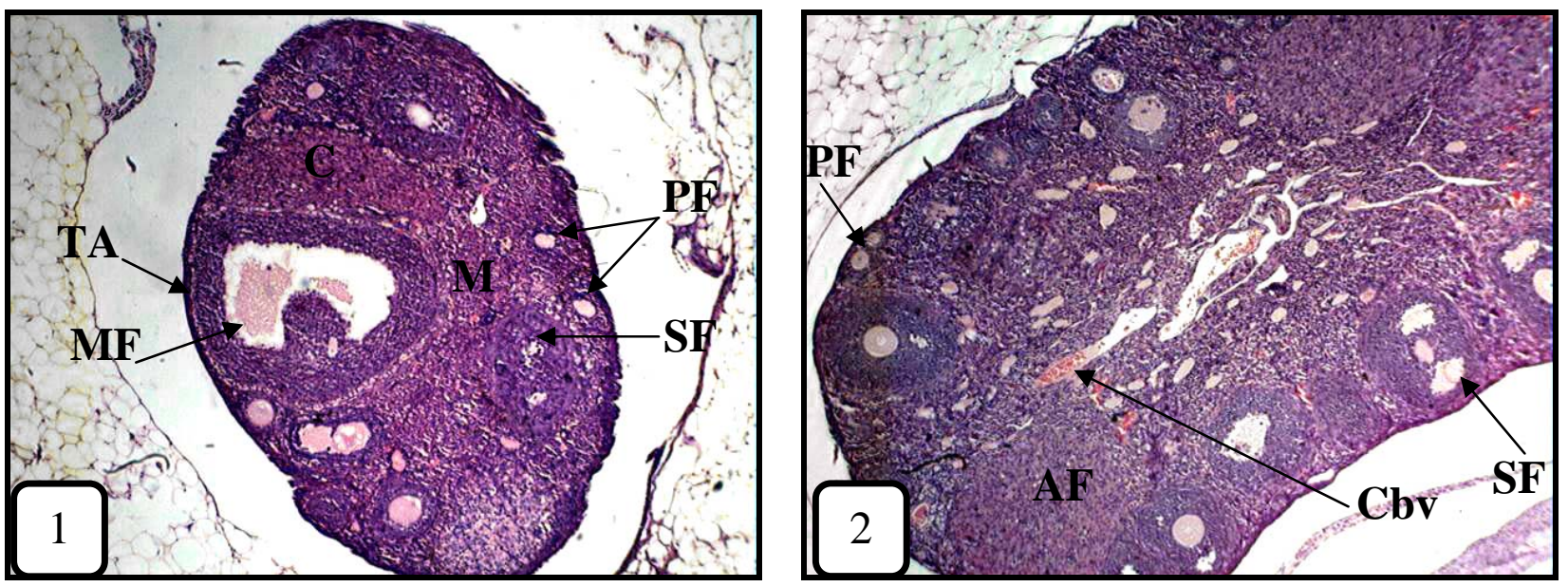

Fig. 1: Section of the ovary of the control female mice Mus musculus showing covering epithelium (tunica albuginea)-TA, Cortex-C, Medulla-M, Primary follicle-PF, Secondary follicle-SF, mature follicle-MF. H and E. X60

Fig. 2: Section of the ovary of the second trated female mice with $250 \mathrm{mg} / \mathrm{kg}$ of A.excelsa for 2 weeks showing increase of secondary follicle-SF, atretic follicle-AF, Congestion of blood vessels Cbv. H and E. X60.
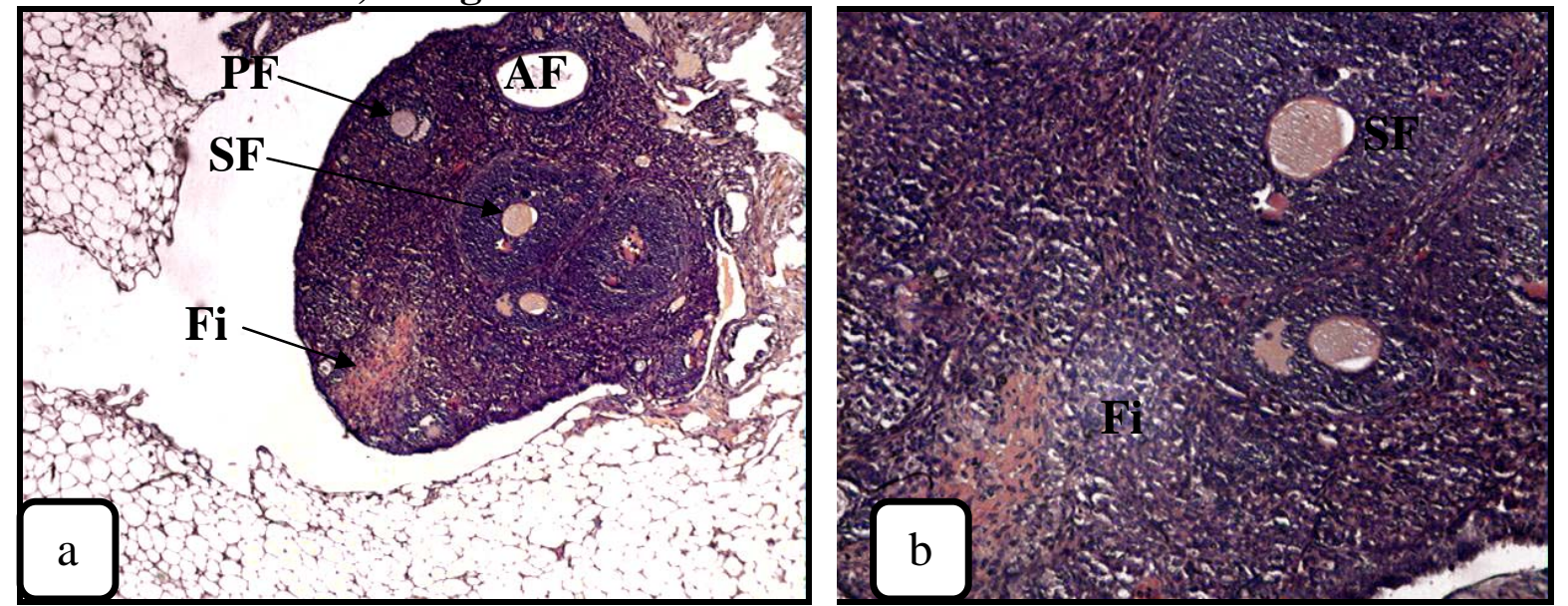

Fig. 3a: Section of the ovary of the third treated female mice with $250 \mathrm{mg} / \mathrm{kg}$ of A.excelsa for 4 weeks showing deccrease the primary and the secondary follicles-PF, SF, Presence atretic follicle-AF, fibrosis of the ovarian cortex-Fi. $H$ and $E$. X60.

Fig. 3b: Section of the ovary of the third treated female mice showing fibrosis of the ovarian cortex-Fi. $H$ and $E$. X150. 


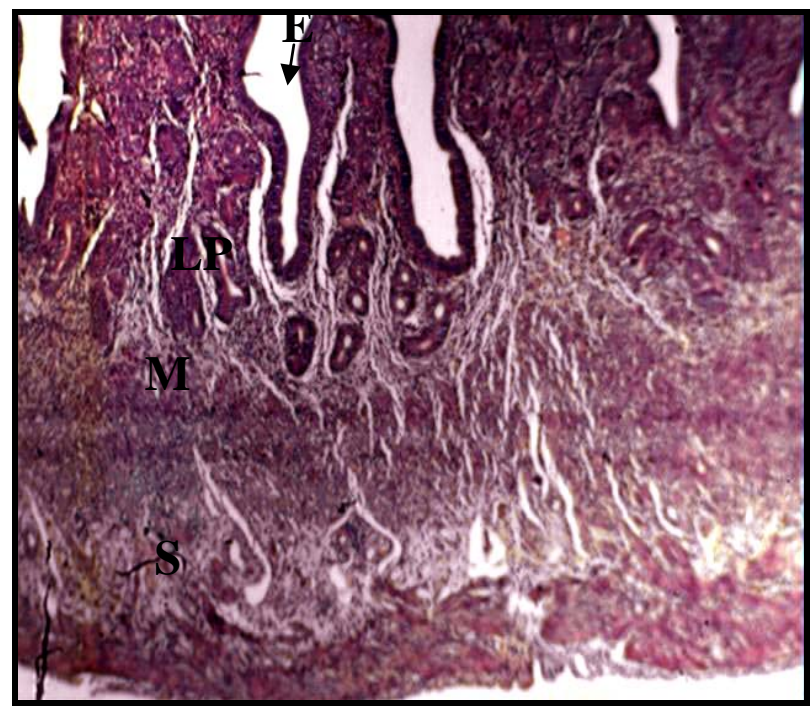

Fig. 4: Section of the uterine of control female mice showing endometrium-E (Single layer of columnar epithelium). Deep to it, the lamina properia-LP, myometrium-M and Serosa-S. $H$ and E. X60.

The uterus sections of the second treated group showed fibrosis of the uterus wall, increased the smooth muscle cells and connective tissue, hyperplasia of smooth muscles (myometrium) and protrusion it to the uterus cavity which caused rupture the endometrium layer. (Fig. 5, a, b). The uterus section of the third treated group showed papilloma in the endometrium, congestion of blood vessels in serosa. (Fig. 6, a, b).
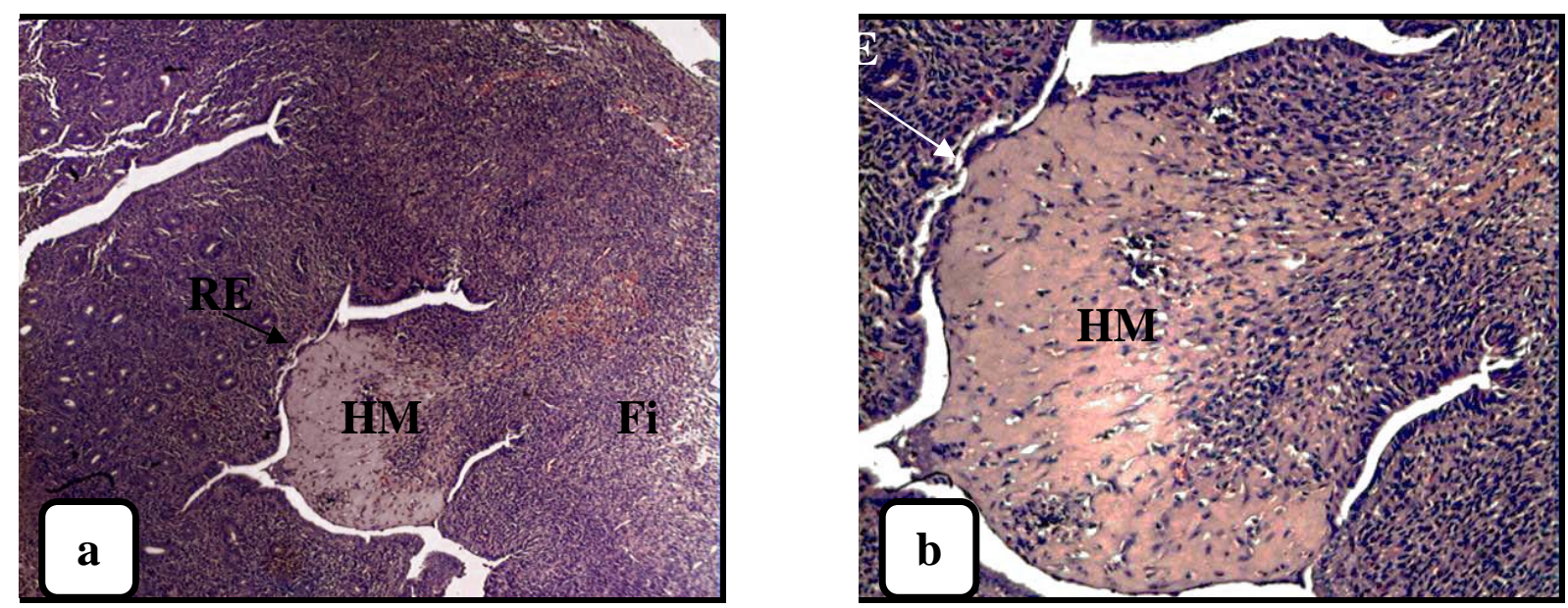

Fig.5 a: Section of the Uterine of the second treated female mice showing fibrosis of the uterus wall-Fi, hyperplasia of myometrium-HM, rupture of the endometrium layer-RE. H. and E. X60.

Fig. 5 b: Section of the uterine of the second treated female mice showing hyperplasia of the myometrium-HM, repture of endometrium-RE. H. and E. X150. 

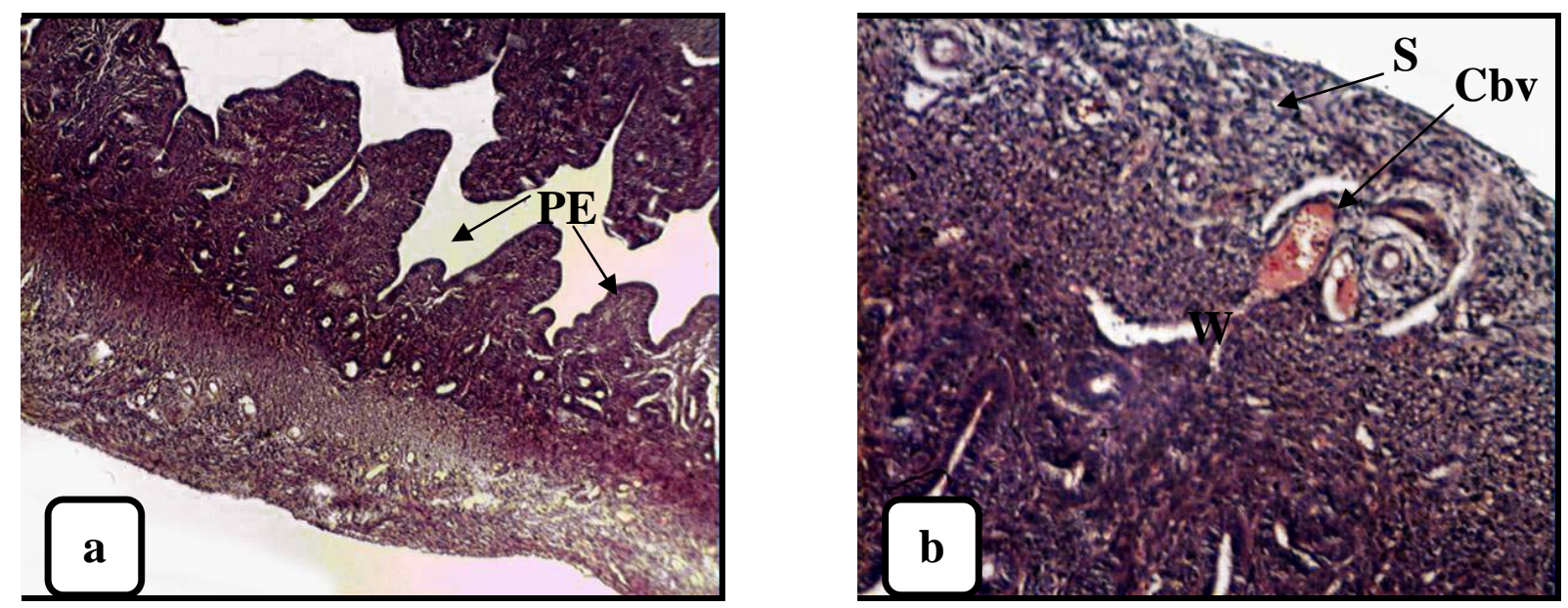

Fig 6 a: Section of the uterine of the third treated female mice showing papilloma of the endometrium-PE, $H$. and E. X60

Fig 6 b: Section of the utrine of the third treated female mice showing congestion of blood vessels of serosa-Cbv. H. and E. X150.

A. excelsa leaf extract caused significant increase $(\mathrm{p}<0.05)$ of serum progesterone and estrogen levels of treated groups compared with control, Table (1).

Table 1: The serum hormonal levels of progesterone and estrogen in control and treated groups of female mice

\begin{tabular}{|c|c|c|c|}
\hline Group & Dose $\mathbf{~ m g} / \mathbf{k g}$ & $\begin{array}{c}\text { Progesterone mg/ml } \\
\text { Mean } \pm \text { SE }\end{array}$ & $\begin{array}{c}\text { Estrogen } \mathbf{~ p g} / \mathbf{m l} \\
\text { Mean } \pm \text { SE }\end{array}$ \\
\hline Control & $0.2 \mathrm{ml} \mathrm{D.W.}$ & $0.8 \pm 0.04$ & $63 \pm 0.31$ \\
\hline Treatment (1) & $\begin{array}{c}250 \mathrm{mg} / \mathrm{kg} \\
(2 \mathrm{weeks})\end{array}$ & $1.02 \pm 0.02$ & $68.6 \pm 0.50$ \\
\hline Treatment (2) & $\begin{array}{c}250 \mathrm{mg} / \mathrm{kg} \\
(4 \text { weeks) }\end{array}$ & $1.08 \pm 0.03$ & $71.2 \pm 0.37$ \\
\hline
\end{tabular}

No. (5 females) pg=pacogram

The results observed that the mean number of newborn decreased in the second and third group as compared with the control group, but there was no difference in the fertility index of the treated and control groups. Table (2).

Table 2: Effect of Azadirachta excelsa leaf extracts on mean number of newborn and fertility percentage of six treated females

\begin{tabular}{|c|c|c|c|c|}
\hline Group & Dose mg/kg & $\begin{array}{c}\text { No. of females } \\
\text { pregnant }\end{array}$ & $\begin{array}{c}\text { Mean No. of new } \\
\text { born } \pm \text { SE }\end{array}$ & Fertility \% \\
\hline Control & $0.2 \mathrm{ml}$ D.W. & 6 & $7.83 \pm 0.30$ & 100 \\
\hline Treatment (1) & $\begin{array}{c}250 \mathrm{mg} / \mathrm{kg} \\
(2 \mathrm{weeks})\end{array}$ & 6 & $4.66 \pm 0.33$ & 100 \\
\hline Treatment (2) & $\begin{array}{c}250 \mathrm{mg} / \mathrm{kg} \\
\text { (4 weeks) }\end{array}$ & 6 & $3.00 \pm 0.36$ & 100 \\
\hline
\end{tabular}




\section{DISCUSSION}

This study investigated the effect of leaf extract of Azadirachta excelsa on histomorphology of the ovary and uterus, Serum levels of progesterone, estrogen and the fertility of female albino mice.

The ovary is the female sex organ and site for oogenesis and estrogen secretion, while the uterus functions in the implantation and nourishment of the developing zygote, Young and Heath (2004). Oogenesis process is influenced by (Follicle stimulating hormone) FSH and (Luteinizing hormone) LH hormone of the anterior pituitary, as well as progesterone and estrogen produced by the sex organs, Murray et al., (2000).

The results of this study revealed histological changes in the ovaries and uteri of the treated female mice indication increased secondary follicles, absence the mature follicles, presence the atretic follicles and congestion of blood vessels in medulla of the ovary (Fig. 2,3) and fibrosis of the uterus wall, Hyperplasia of smooth muscles (myometrium) and Protrusion to the uterus cavity in the second treated group, but in the third treated group showed papilloma of the endometrium and congestion of blood vessels (Fig. 5,6). In this study the effects caused a decrease in the number of follicles of the third treated group after 4 weeks. This probably be the reason for the inhibition of the folliculogenesis and presence of the atretic follicles. These results are in agreement with Upadhyay, et al., (1990). Gbotolorun, et al., (2004). Roop, et al., (2005). They reported that A. indica oil extract caused partial blockage of ovulation, folliculogenesis inhibition, prolonged diestrous. This is also in line with the work of Mandal and Dhaliwal (2007). They reported alterations in morphology and function of the uterus in rats treated with the seed extract of neem (A.indica). This study is however at variance with Akpantah, et al., (2010), they reported that no pathological effects in the ovaries and uteri of female rats treated with 200, 400 $\mathrm{mg} / \mathrm{kg}$ of $A$. indica leaf extract.

This study investigated a significant increase in progesterone and estrogen levels in the treated groups. This may suggest that $A$. excelsa leaf extacts stimulated ovarian, which may have resulted in subsequent stimulation of progesterone and estrogen synthesis. This study in line with Akpantah et al., (2010) who reported higher progesterone levels in female rats treated with $A$. indeca leaf extracts. While Prakasha et al., (1988), reported that $A$. indica oil did not possess any estrogenic, anti-estrogenic of progestational activity, while appearing not to have interfered with actions of progesterone.

The results showed a decrease in the number of litters born of treated groups compared with the control group. This is related to the effect of $A$. excelsa leaf extract on fertility. The uterus is the main site of antifertility effects, thus the extract may have caused antiimplantation, on the other hand the implantation exact equilibrium of estrogen and progesterone is essential, and disturbance in levels of these hormones causes infertility. This study in line with Shaher (2009) who reported that the A. excelsa leaf extract resulted antfertility in male mice. Mandal and Dhaliwal (2007). They reported the average number of embryos and implantation losses in pregnant female rats treated with Melia azedarach seed extract. This is also in agreement with Yadav et al., (2013). They reported the emulsion of six plant includes Ailanthus excelsa stem bark and $A$. indica leaves show less number of implant (at $50 \mathrm{mg} / \mathrm{kg}$ b.w.) and resulted antifertility activity in the treated female rats. In conclusion, the present study suggests that the antifertility activity of the extract is probably due to its antioestrogenic property and anti-implantation. 


\section{REFERENCES}

Akhtar, Y.; Yeoung, Y.R.; Isam, M.P. (2008). Comparative bioactivity of selected extracts from meliaceae and some commercial botanical insecticides against two noctuid conterpillars, Trichoplusia ni and pseudaletia unipuncta. Phytochemistry reviews 7(1), 77-88.

Akpantah, A.O.; Ekong. M.B.; Uruakpa, K.C.; Akpaso, M.; Eluwa, M.A.; Ekanem, T.B. (2010). Gonadal histo-morphologies and serum hormonal milieu in female rats treated with Azadirachta indica leaf extract. Indian J. Reprod. Med. 8(4), 185-190.

Al-Hajj, H.A. (2010). "Optical Laboratory Preparations". 1st ed. Dar Al-Maseera, Aman, Jordan.

Chungpongse, S.; Buranatham, W. (1991). "Azadirachta excelsa (Jack) Jacob". Songkhla Nursery center, Songkhla, Thailand, pp.10-15.

Doll, M.; Schumuttere, H. (1993). Vergeich der Wirkung von samenkernextrakten und olvon Azadirachta excelsa (Jack) (A. intergrifoliola Merr.) und Azadirachta indica (A.Juss) beim Mexikanischen Bohenenkafer Epilachna Varirestis (Muls.) Mitt Dtsch. Ges. Allg. Angew. Entomol. 8, 775-780.

Garg, S.; Talwar, G.P.; Upadhyay, S.N. (1998). Imunocontraceptive activity of guided fractionation and Characterization of active constituents of neem (Azadirachta indica) seed extracts. J. Ethnopharmaeol. 235-246.

Gbotolorum, S.C.; Oremosu, A.A.; Noronoha, C.C.; Okanlawon, O.A. (2004). The effect of alcohol extract of neem seed on ovulation, esrous cycle and fertility of adult cyclic Sprague-Dawly rats. Nig. J. Health Biomed. Sci. 3,116-119.

Hein, D. (1994). Gegenstrom chromate-graphische Reinigung biologisch Tetranotriterpenoide aus Samen des Neim (Azadirachta indica A. Juss) und Marrangoboumes (Azadirachta excelsa Jack) und ihre NMR-Spektrometrische charakterisierung. Diploma thesis, Univ. of Glessen.

Lean, T.N.; Yuen, P.M.; Loke, W.H.; Abdulkadir, A. (2003). Effects of Azadirachta excelsa on feeding behavior, body weight and mortality of Crocidolomia binotalis. Zeller (Lepidoptera: pyralidate). J. Sci. Food Agricul. 83(13), 1327-1330.

Luna, H.C. (1968). "Manual of Histological Staining Methods of the Armed Force Institute of Pathology". 3rd McGrow-Hill Book Co., New York.

Ma, A.; Wang, X.; Gong, X.; Zhao, X.; Zhong, X. (2012). Protective effect of anti-abortive herbal medicine on embryo implantation and the changes of Serum Progesterone, IFN- $\gamma$ and IL-4 in cow after artificial insemination. J. Med. Plants Res. 6(3), 383390.

Mandal, R.; Dhaliwal, P.K. (2007). Antifertility effect of Melia azedarach Linn. (dharek) seed extract in female albino rats. Indian J. Exp. Biol. 45, 853-860.

Murkherjee, S.; Garg, S.; Talwar, G.P. (1999). Early post implantation contraceptive effects of purified fraction of neem (Azadirachta indica) seed given orally in rats. Possible mechanisms involved. J. Ethanopharmacol. 67, 287-296.

Murray, R.K.; Granner, D.K.; Mayes, P.A.; Rodwell, V.W. (2008). "Harper's Biochemistry". 25th ed. London; Appleton and Lange.

Nor Aini, A.S.; Seong, L.K. (2006). Azadirachtin variation of six provenance of Azadirachta excelsa (Jack) Jacob. Pakistan J. Biol. Sci. 9(5), 833-836. 
Parshad, O.; Singh, P.; Gardner, M.; Flectcher, C.; Rickards, E.; Choo-Kang, E. (1994). Effect of aqueous been (Azadirachta indica) extract on testosterone and other blood constituents in male rats. A Pilot Study West Indian Med. J. 43, 71-74.

Prakasha, A.O.; Tewaria, R.K.; Mathur, R. (1988). Non-hormonal post-coital contraceptive action of neem oil in rats. J. Ethnopharmacol, 23,53-59.

Ragi, Y.; Udoh, US.; Mewoyeka, O.O.; Ononye, F.C.; Bolarinwa, A.F. (2003). Implication of reproductive endocrine malfunction in male antifertility efficacy of Azadirachta indica in rats. Afr. J. Med. Sci. 32, 159-165.

Roop, J.K.; Dhaliwal, P.K.; Guraya, S.S. (2005). Extracts of Azadirachta indica and Melia azedarach seed inhibit folliculogenesis in albino rats. Braz. J. Med. Biol. Res. 38, 943-947.

Sadre, N.L.; Deshpande, V.Y.; Mendulkar, K.N.; Nandal, D.H. (1983). Male antifertility activity of Azadirachta indica in different species Rauischhol zhausen. pp. 473482.

Schumuttere, H.; Doll, M. (1993). The marrango on Philippine neem tree, Azadirachta excelsa (A-intergrifoliola): A new source of insecticides with growth-regulation properties. Phytoparasitica. 21, 79-86.

Shaher, W.S. (2009). Effect of Azadirachta excelsa (Jack) leaf extracts on reproductive organs and fertility of male albino mice (Mus musculus). J. Raf. Sci, 20(3), 1-9.

Upadhyay, S.N.; Kaushic, C.; Talwar, G.P. (1990). Antifertility effects of neem oil by single intrauterine administration: Anoval method for contraception. Proc. R. Soc. Lond. B. Biol. Sci. 242, 175-179.

Yadav, M.; Singh, D.P.; Verma, C.; Singh, S.; Saini, A.; Dubey, A. (2013). Development of Multicomponent herbal formulation and its evaluation for antifertility activity. Int. J. Pharm. and Phytopharm. Res. 2(4), 277-282.

Young, B.; Heath, J.W. (2004). "The Endocrine Glands". In young, B., Heath, J.W eds. Wheater's functional histology: a text and colour atlas. Churchill Livingstone. pp. 310-327. 